\title{
Impact of Accountant Resource on Quality of Accounting Information System: Evidence from Vietnamese Small and Medium Enterprises
}

\author{
Vu Thi Thanh Binh*, ${ }^{*}$, Nhat-Minh Tran ${ }^{2}$, Do Minh Thanh ${ }^{3}$, Nguyen Thi Hong Nga ${ }^{1}$ \\ ${ }^{1}$ Hanoi University of Industry \\ ${ }^{2}$ National Economics University \\ ${ }^{3}$ Thuongmai University
}

\section{ARTICLE INFO}

\section{Article history:}

Received 23 December 2019

Accepted 03 February 2020

Published 31 March 2020

\section{Keywords:}

Accountant Resource

Performance measurement

Quality of accounting information

system

SMEs

\begin{abstract}
Improving the quality of accounting information systems through accountant resources is beneficial to the performance and sustainable development of SMEs. This study investigated the impact of accountant resources on the quality of accounting information systems in Vietnamese SMEs. Accounting information system quality was measured by a multidimensional scale including system quality, information quality, and usefulness. The study tested hypotheses using Path analysis of Structural Equation Model based on 434 respondents. The findings indicated a strong interaction between the components of the accounting information system quality under the effect of accountant resources. The results showed a positive direct effect of accountant resources on system quality and the path analysis results also revealed an influence of accountant resources on information quality and usefulness via mediating variables. The results highlighted the importance of accountant resources for the quality of accounting information systems. This study contributed theoretically to the non-financial indicator for measuring accounting information system quality.
\end{abstract}

\section{Introduction}

Small and medium enterprises (SMEs) are the center in the economies of several countries that contribute a significant rate of gross domestic product. SMEs account for a large proportion of total number enterprises in economic systems around the world, for example, from $96 \%$ to $99 \%$ of all companies in OECD nations (Scupola, 2009) or up to over 98\% in Vietnam (MPI, 2017; VCCI, 2017). Comparing to large companies, SMEs have many advantages such as adaptable, more capable of creativity and resilience faster in a competitive environment (Salavou, 2004), effectively connected information systems in a globalization trend period (Gunasekaran, Rai, \& Griffin, 2011). In contrast to the advantages, SMEs also face off various issues such as lack of resources (Delone, 1988), difficulties to receive funding and the trouble of transparency and information asymmetry (Ghorbel, 2017). In Vietnam, SMEs are vulnerable to economic fluctuations, so the negative impacts of the business environment lead many businesses to make losses and withdraw from the market in Vietnam (MPI, 2017). In general, Vietnamese SMEs are important economic components as well as a vital contributor to employment and innovation creation, but they get a lot of barriers to their growth and innovation.

The accounting information system is a driver for the development of SMEs. An accounting information system is a subsystem of the management information system (MIS) that plays crucial roles in formulating and calculate organizational strategy to reinforce financial control (Chenhall, 2003). The accounting information system brings paramount information for stakeholders to make effective decisions also to assure the organizational competitiveness

\footnotetext{
* Corresponding author.

E-Mail address: vuthithanhbinh@haui.edu.vn

ORCID: 0000-0001-5139-5776
} 
(Saganuwan, Ismail, \& Ahmad, 2013), affect business strategy implementation (Uyar, 2019) and provide information for corporate sustainability (Perrini \& Tencati, 2006). Moreover, it is useful for decrease fraud and errors (Ngo, Le, \& Nguyen, 2013) and improves the efficiency of the integration process to economic agreements in Vietnamese SMEs (Phan \& Pham, 2015). However, Vietnamese SMEs are not equipped with adequate accounting information systems when their information sophistication mainly focuses on accounting applications for bookkeeping functions than planning and controlling functions (Binh, 2017). Additionally, a low rate of SMEs applies decision support systems, computer-aided manufacturing and computer-assisted production management in their technological sophistication (Binh, 2017). Because of its importance, the accounting information system has become progressively concerned in management in general and in management control research in recent years (Merchant \& Van der Stede, 2011).

Implementing an accounting information system provides managers with a meaningful tool to govern activities and to curb business disadvantages. Quality is a non-financial indicator of performance measurement (Neely, Gregory, \& Platts, 1995). So a huge number of researchers carry out to evaluate the quality of accounting information systems also factors influencing accounting information system quality. Assessing accounting information system quality is a topic of great interest and accounting information system quality measures are diverse. Some preceding studies have used one dimension to measure the quality of accounting information systems. For example, the studies of Dehghanzade, Moradi, and Raghibi (2011) and Oakes (2006) have employed accounting information quality as a measure while others, such as Boulianne (2007) and Sajady, Dastgir, and Nejad (2008), adopted organizational performance measure. However, recent studies have shown a significant tendency to use the multidimensional scale by a combination of constructs because accounting information system effectiveness does not have a single measure to explain (Delone \& McLean, 2003). Chalu (2012) has extended to Delone and McLean's opinion and suggested that measurements of accounting information effectiveness need to illustrate "output-orientation, systems-orientation, and user-orientation and organizational orientation". Multi-dimension measures are better by fully illustrating aspects of measuring accounting information system quality. Multidimensional measurement has been used by researchers for information systems such as MIS, e-commerce systems, e-learning systems. In Vietnam, the study of Huynh and Nguyen (2013) has proposed a combination scale to measure the quality of accounting information systems but lack of empirical evidence for this measure.

Accountants are an indispensable component in an accounting information system that impacts on quality of accounting information systems. Accountants not only carry out accounting information system functions but also are end-users of the system (Hall, 2011). In SMEs, accountants play both the role of a consultant in accounting services and the role of business advisers (Gooderham, Tobiassen, Døving, \& Nordhaug, 2004). Accountants have an impact on the quality of accounting information systems, for example, the qualifications of accounting staff have a great influence on the quality of accounting information systems (Chalu, 2012). Or the individual characteristics of an accountant is an efficient factor of computer-based accounting information system effectiveness (Dehghanzade et al., 2011). However, there is a lack of evidence from Vietnam, especially in the SME context, relating to the impact of accountants on the quality of accounting information systems.

As noted above, the topic of accounting information systems has been increasingly concerned about measuring and evaluating the impact of factors in SMEs in Vietnam. But there is a gap in measuring the quality of accounting information systems and evaluating the impact of accountant resources on the quality of accounting information systems. Aim to fill these gaps, this study has two objectives. The first objective of this research is to investigate an interaction among three constructs including system quality, information quality, and usefulness that represent the quality of accounting information systems under the influence of accountant resources. The second objective is to explain how much accountant resources impact on the quality of accounting information systems in the context of Vietnamese SMEs.

This study makes several contributions. Our research provides a comprehensive examination of the quality of accounting information systems, measured by multidimensional constructs including system quality, information quality, and usefulness. We highlight that accounting information system quality components are separate but strongly interdependent, in which system quality has the greatest influence on usefulness and information quality. Our results provide evidence for a significant direct effect of accountant resources on system quality but reject its direct influence on information quality as well. However, our research proves an indirect linkage between accountant resources and the other two components of the accounting information system quality. 


\section{Literature review}

\section{Quality of accounting information systems}

Accounting information system is an essential subsystem in the management information system (Allahverdi, 2011), which offers some functions including collecting, analysing, categorizing, and reporting with key purpose is to convert input data into useful information (Boockholdt, 1995). With plentiful data sources, timely processing, and rapid transmission, the accounting information system is beneficial for enterprises (Shen \& Han, 2019). In recent years, accounting information system research has become progressively concerned in both general management and management control research (Merchant \& Van der Stede, 2011). AICPA (1966) stated "accounting is information system" while American Accounting Association defined that accounting information system is a system that "gathers, classified, and compiles data to offer to internal and external decision-makers". In SMEs, accounting information system is an organized structure of mandatory subsystem to generate accounting information which supports managers to run their company (Chapellier, Mohammed, \& Teller, 2013) and helps firms develop business cooperation and share knowledge (Levy, Loebbecke, \& Powell, 2003). Accounting information systems have an important role which is a mechanism to enlarge organization financial control through formulating and calculating firm strategy (Chenhall, 2003). It is a tool of firms that producing information for managing functions, such as planning, controlling and decision-making (Saganuwan et al., 2013).

According to Meiryani (2015), the quality of accounting information system is "an integrated system of accounting information from the various components of accounting information systems are interconnected and work together in harmony to process financial data into useful accounting information for users" (page 82). Nicolaou (2000) also mentioned the term accounting information system integration to define the effectiveness of the accounting information system. In this study, the quality of accounting information systems is defined as an integrated system of different components to take over accounting functions such as collecting, classifying, analysing, and communicating data into useful information for stakeholders.

\section{IS success model in the context of accounting information system}

To answer the question about measuring dependent variables of information system (IS) field, Delone and McLean (1992) proposed a dependent variable called IS success and recapitulated six interrelationship variables representing IS success. Six variables of the primary IS success model includes: system quality, information quality, use, user satisfaction, individual impact and organizational impact that were separate but interdependent. The authors called for more studies to confirm their model. Pitt, Watson, and Kavan (1995) suggested an additional construct, service quality, into the IS success model. While Seddon (1997) excluded Pitt et al. (1995) interpretation because service quality is to measure the quality of the IS department not "application of information technology", Delone and McLean (2003) added service quality to the upgraded IS success model. Another discussion from Seddon and Kiew (1996) that use would be suitable for voluntary systems, with mandatory systems such as accounting information systems, usefulness would be better. The usefulness construct that Seddon and Kiew (1996) mentioned was commonly used in Technology Acceptance Model (TAM) by Davis (1989). Although Delone and McLean (2003) didn't upgrade usefulness in their model, a lot of researchers still picked up usefulness construct in the context of mandatory systems. The updated IS success model of Delone and McLean (2003) had some modifications with six components comprise system quality, information quality, service quality, use, user satisfaction, and net benefit. However, Delone and McLean (2002) stated that system quality and information quality are the best measures if only a single system is considered, but the service quality is an important variable in the model when evaluating the success of the IS department.

The measures of the quality of accounting information systems are very diverse and can be used individually or in combination. Petter, Delone, and McLean (2008) argued that the selection of constructs depends on the context such as the nature of the firm, the purpose of the system. So in this study, system quality and information quality are picked up because they are the best measures for every information system (Delone \& McLean, 2002). Also, in the context of the accounting information system, a mandatory system, usefulness is a suitable measure to evaluate the quality of accounting information systems (Seddon \& Kiew, 1996). Meanwhile, service quality is used better for assessing the information technology department than the application of information technology (Seddon \& Kiew, 1996), so, this measure is less appropriate with the context of Vietnamese SMEs. Moreover, user satisfaction is not to include in this model because lots of items of user satisfaction measurements already mapped and included in 
system quality and information quality (Gorla, Somers, \& Wong, 2010). Therefore, three components include system quality, information quality and usefulness are proxies for accounting information system quality. These constructs are separate but interdependent, and their relationships are temporal, not causal influences (Seddon, 1997).

\section{Accountant resource}

In the organization, accountant resource is the human capital which is knowledge, skills, and abilities to provide professional services (Sagara, 2015). Accountant resource is an element of accounting information system (Allahverdi, 2011; Romney \& Steinbart, 2015) that related to data input and producing the output of accounting information system (Al-hiyari, Al-Mashregy, Mat, \& Alekam, 2013). For the detail, accountant resource is those who directly conduct accounting functions such as collecting, processing data, analysing, and communicating information (Hall, 2011). Evidence from recent research has recognized an important role of accountant resources in accounting information system success. Accountants play roles as a user, designer, and controller of the accounting information system (Hall, 2011) that means accountant resource have responsibilities for sharing with the information technology specialist to develop applications in the accounting information system. Accountants participate in every stage of accounting information system cycle from planning, analysing, designing, implementing, and assessing the accounting information system performance that leads to minimize system-related risks and make the system more appropriate (Okab \& Al-Oqool, 2014) and make accounting information more relevant (Al-hiyari et al., 2013). Especially in SMEs, the accountant resource also plays an advisory role for the executive board in decisions about internal planning, business decision-making, or controlling (Gooderham et al., 2004). Therefore, the development cycle of an accounting information system that ignores the accountant resource role will lead to ineffective or even failed systems (Meiryani, 2014).

\section{Research mode and hypotheses}

The conceptual model of this study is showed in Figure 1, in which the quality of accounting information systems is a multi-dimension measure. System quality, information quality, and usefulness focus on user perception with information generating from the accounting information system. Three constructs of accounting information system quality are separate but interrelationship.

Seddon and Kiew (1996) debated that in mandatory systems such as the accounting information system, the transmission of useful information for a certain time is one of the most regular measures of success system. So usefulness is a good measurement, replaced for the use in the context of mandatory system (Seddon \& Kiew, 1996). The usefulness of accounting information systems is the degree to which one believes that the use of accounting information system will improve their job performance (Davis, 1989). Usefulness measure consists of improving job performance, improving productivity, enhancing job effectiveness and useful in work (Liao, Chen, \& Yen, 2007). An accounting information system is useful if it creates benefits for the organization and the benefits of use are much greater important than costs.

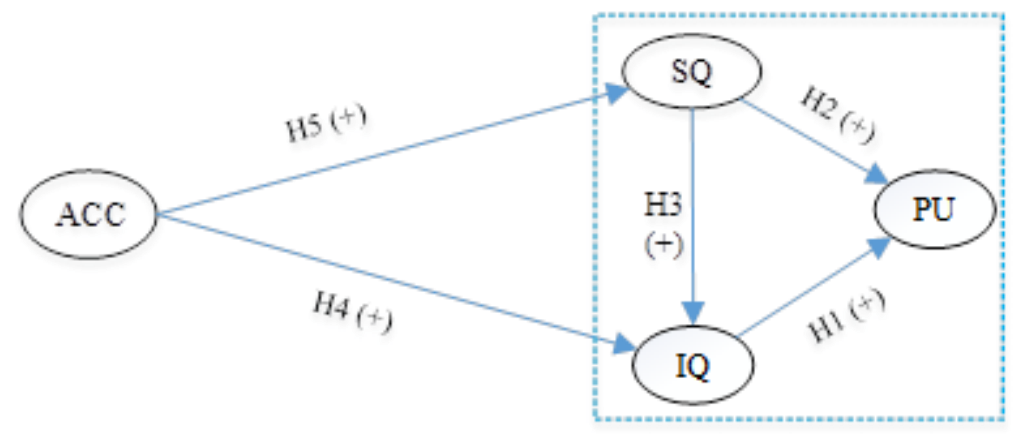

Figure 1. The conceptual model

Information quality attributes to the outputs of the accounting information system that is concerned with the characteristics of information. Delone and McLean (1992) suggested that information quality should measure the quality of information system output which is generated from an accounting information system and performed in accounting reports. Information quality refers to the characteristics as accurate, relevant, and timely information generated from accounting information systems (Seddon, 1997). Gorla et al. (2010) in a study relating IT investment in accounting information systems refers to information quality in the form of the online screen and printed reports. 
So information quality related to both information content and information format. Information content includes the characteristics of accuracy, completeness, conciseness, usefulness for the daily job, relevance for decision making while information formats are good appearance and format, comparable to other outputs, easily to understand (Gorla et al., 2010). Kraemer, Danziger, Dunkle, and King (1993) debated that better information quality will result in higher usefulness. Empirical evidence of Seddon and Kiew (1996) by using OLS regression and path analysis supported that increasing information quality causes a rise in usefulness. we hypothesize that

H1: Improving information quality will result in increasing usefulness in accounting information systems.

System quality is one of the most important indicators of IS success that interprets measures of the information producing system itself (Delone \& McLean, 1992). System quality is related to whether or not "error" in the system, user interface consistency, ease of use, document quality and the quality and maintainability of the coding program (Seddon, 1997). System quality measures declare user perceptions of reciprocal action with accounting information system over time (Nelson, Todd, \& Wixom, 2005) that include easy to learn, equipped only with useful features and functions, flexible to make changes, well-integrated, user-friendly, good documentation, short response time for online inquiry, and short time lag between data input and output for batch processing (Gorla et al., 2010). Organizations improving system quality can trigger a rise in information system usefulness (Sabherwal, Jeyaraj, \& Chowa, 2006; Seddon \& Kiew, 1996). Higher system quality is as easier to use, thus, it has higher levels of usefulness (Davis, 1989). Furthermore, an inadequate system most probably causes low system output that puts firms into a less competitive advantage position (Gorla et al., 2010). In other words, there is a linkage between information quality and system quality (Fitriati \& Susanto, 2017; Gorla et al., 2010; Susanto, 2017). Therefore, we propose hypotheses:

H2: System quality is expected to facilitate usefulness.

H3: Enhancement in system quality will lead to enlargement in information quality.

Accountant resource is the significant driver who improving quality of accounting information system in SMEs because of the role of business advisers (Gooderham et al., 2004). Accountant resource measures include the longterm relationship of accountants with the firm, competence in statutory accountancy services, competence in business advisory services (Gooderham et al., 2004). Several studies strengthened the influence of accountants on the quality of accounting information systems (Binh \& Luan, 2017; Chalu, 2012; Iskanda, 2015; Ismail, 2009; Taber, Alaryan, $\&$ Haija, 2014). Accountants as end-users who perform their needs about accounting information system to designer relating specified accounting rules, algorithms in the system like the depreciation model. The quality of accounting personals affects the characteristics of accounting information (Zhou, 2010). Hence, Chalu (2012) addressed the impact of qualification of accounting staff on system quality and information quality. The above discussion leads to the following hypotheses:

H4: Accountant resource is positively associated with information quality.

H5: Accountant resource is positively associated with system quality.

\section{Methodology}

The research method illustrates measurement for the constructs of accounting information system quality and accountant resources as well as collecting data procedures. Then the study validates the instruments based on confirmatory factor analysis and tests hypotheses using path analysis in the structural equation model (SEM).

\section{Measurement and instrument validation}

Our questionnaire comprises two-part: the first part collects demographic of respondents, the second part measures variables related to 5 hypotheses. This research used perceptual measures. To avoid common method variance phenomena by using perceptual measure in both independent variable and dependent variable, we applied a technique Chang, Van Witteloostuijn, and Eden (2010) suggested in their article. By adopting diverse measures from different studies as well as utilizing various scales, we expected to decrease common method variance phenomena. All construct measurements were selected from prior studies. Specifically, we picked up two constructs system quality and information quality, from Gorla et al. (2010), usefulness construct from Liao et al. (2007), and accountant resource was picked up from Gooderham et al. (2004). The research use 7-point Likert scale with usefulness, system quality, and information quality and 5-point Likert scale with accountant resource.

English is not a native language nor used frequently in daily communications in Vietnam while all questionnaire items used in this study are sourced from English questionnaires. From our experience in previous business surveys, we found that it is very difficult to collect data so it is necessary to carefully design the questionnaire to avoid re- 
conducting the survey. We implemented a pretest and pilot test to examine the psychometric properties of construct items. After translating construct items into Vietnamese, we did a pretest by interviewing a professional who majored in accounting and used English fluently to translate the questionnaire parallel. And then, we continued pretesting with 5 people including one manager, two chief accountants, and two accounting staff to ensure the articulation as well as comprehensiveness in the questionnaire. From the pretest result, we continued to correct the questionnaire. Finally, we did a pilot test with 50 respondents to test data entry and procedures of data processing.

\section{Sample framework}

In Vietnam, there are several criteria to classify SME such as total equity, labor, or revenue (Government, 2018) and total equity is applied in this study. The sample framework consists of SMEs operating in Hanoi, is capital as well as is concentrated the second largest number of businesses in Vietnam (VCCI, 2017). There is approximately 232,000 SMEs account for above 97\% of the total number of enterprises in Hanoi (Quang Phu, 2018). This research concerns SMEs running more than one year due to firms need time to implement their system and to communicate financial statements, thus, this condition makes it easy for the respondent to select their company's total equity on the questionnaire.

\section{Data Collection}

Data collections applied convenience sampling and data is gathered by using a closed questionnaire via email registered with tax authorities and Facebook Messenger. This research chose an online survey because of the popularity of the internet used in academic papers (Bhattacherjee, 2001). The online survey link was sent to the firm's email list of three tax authorities. Besides, we messaged to members in "Gia đình kế toán" (Accountant Family) - a big public Facebook group with more than 241.000 members. In a total of 642 responses, 434 respondents were working in SMEs located in Hanoi. This sample size suitable for SEM analysis (Hair, Black, Babin, \& Anderson, 2014).

Table 1 showed the demographics of respondents. The sample demographics are grouped into individual and organizational characteristics. Regarding individual characteristics, $38 \%$ is accounting staff, followed by a general accountant (25\%), CEO (17\%), chief accountant/CFO (17\%), and head of the department (3\%). The distribution of qualification includes $87 \%$ bachelor's degree and $13 \%$ master or higher education. $47 \%$ of respondents have under 3 years of working experience and a declining rate by years of working experience. Regarding organizational characteristics, a high rate of respondents works in commerce and service field (68\%) while the remaining (32\%) worked in other fields (agriculture; industry and construction). 52\% of businesses ownership characteristic is the joint-stock company, followed by the limited liability company, private business, and partnership (36\% and 12\% respectively). Referring to the age of the firm, most firms have the age of 1 - 3 years (52\%) and above 5 years (37\%).

Table 1. Demographic of respondents

\begin{tabular}{lcclcc}
\hline \multicolumn{1}{c}{ Individual characteristics } & No. & \% & Organizational characteristics & No. & \% \\
\hline \multicolumn{1}{c}{ Position } & & \multicolumn{2}{c}{ Business field } \\
Accounting staff & 164 & $38 \%$ & Agriculture & 13 & $3 \%$ \\
General accountant & 109 & $25 \%$ & Industry and construction & 125 & $29 \%$ \\
Chief Accountant/CFO & 74 & $17 \%$ & Commerce and service & 296 & $68 \%$ \\
Head of the department & 15 & $3 \%$ & Ownership & & \\
CEO & 72 & $17 \%$ & Private business, partnership & 52 & $12 \%$ \\
$\quad$ Qualification & & & Limited liability company & 158 & $36 \%$ \\
Bachelor & 393 & $91 \%$ & Joint Stock Company & 224 & $52 \%$ \\
Master and higher education & 41 & $9 \%$ & Age of firm & 224 & $52 \%$ \\
$\quad$ Working experience & & & From 1 to 3 years & 49 & $11 \%$ \\
Under 3 years & 206 & $47 \%$ & From 3 to 5 years &
\end{tabular}




\begin{tabular}{lccccc}
\hline \multicolumn{1}{c}{ Individual characteristics } & No. & \% & Organizational characteristics & No. & \% \\
\hline From 3 to 5 years & 104 & $24 \%$ & Above 5 years & 161 & $37 \%$ \\
From 5 to 10 years & 67 & $15 \%$ & & & \\
Above 10 years & 57 & $13 \%$ & & & \\
\multicolumn{1}{c}{ Total } & $\mathbf{4 3 4}$ & $\mathbf{1 0 0 \%}$ & Total & $\mathbf{4 3 4}$ & $\mathbf{1 0 0 \%}$ \\
\hline
\end{tabular}

\section{Results}

The measurement model is validated through reliability, convergent values and discriminant values by the confirmatory factor analysis (CFA). Structural equation modeling (SEM) using Maximum Likelihood estimation is used to test theoretical models and research hypotheses ( 5 hypotheses). The conceptual model (Figure 1) is described by the visual tools provided by AMOS. Heywood phenomenon does not appear during the estimation of the CFA and SEM model, so it can be concluded that this model is suitable for market data.

\section{Confirmatory factor analysis results}

The measurement model has four constructs including system quality (SQ), information quality (IQ), usefulness (PU), accountant resource (ACC). Firstly, CFA analysis results show that the multiple fit indices complied with the rule of thumb. The correlations between concepts are satisfactory and the results of the concept measurement have reached divergence validity and convergence validity. Indeed, CFA analysis results included chi-square normalized by degrees of freedom (Chi-square/df) being $3.646<5$ (Bentler, 2006), adjusted goodness of - fit index (AGFI) being $0.865>0.8$, goodness-of-fit index (GFI) being $0.903>0.9$, comparative fit index (CFI) being $0.953>0.9$, TuckerLewis Index $(\mathrm{TLI})=0.941>0.9$, root mean square error of approximation $($ RMSEA $)=0.078<0.08$, and standardized root mean square residual $(\mathrm{SRMR})=0.037<0.08$ that indicate a good fit with conceptual model (Gunzler \& Morris, 2015; Henry \& Stone, 1994; Pham, Lai, \& Vuong, 2019). Table 2 shows the details of multiple fit indices

Table 2. Results of multiple fit indices

\begin{tabular}{|c|c|c|}
\hline Index & Result & Acceptable level \\
\hline Chi-square & 448.422 & - \\
\hline Degree of freedom (df) & 123 & - \\
\hline Chi-square/df & 3.646 & $<5$ \\
\hline CFI & 0.953 & $>0.9$ \\
\hline GFI & 0.903 & $>0.9$ \\
\hline AGFI & 0.865 & $>0.8$ \\
\hline TLI & 0.941 & $>0.9$ \\
\hline RMSEA & 0.078 & $<0.08$ \\
\hline SRMR & 0.037 & $<0.08$ \\
\hline
\end{tabular}

Secondly, all constructs showed acceptable convergent validity by testing factor loadings, composite reliability (CR) and average variance extracted (AVE). As shown in Table 3, all factor loadings were greater than 0.55 with a P-value below 0.001 indicating a strong relationship with the construct (Hair et al., 2014). All construct reliabilities ranged from 0.868 to 0.95 and AVEs range from 0.616 to 0.827 , which were higher than acceptable thresholds, 0.7 and 0.5 , respectively. Finally, to test discriminant validity, this study used chi-square difference tests to compare with AVE scores. The results in Table 4 illustrated discriminant validity for all constructs. 
Table 3. Results of factor loading for CFA

\begin{tabular}{|c|c|c|}
\hline Items & Factor Loading & P-value \\
\hline Accountant Resource (Gooderham et al., 2004) & \multicolumn{2}{|c|}{ (Likert 5-point scale) } \\
\hline ACC1: Long-term relationship with the firm & 0.766 & $* * *$ \\
\hline ACC2: Perceived competence in statutory accountancy services & 0.860 & $* * *$ \\
\hline ACC3: Perceived competence in business advisory services & 0.856 & $* * *$ \\
\hline System Quality (Gorla et al., 2010) & \multicolumn{2}{|c|}{ (Likert 7-point scale) } \\
\hline \multicolumn{3}{|l|}{ Our information systems are: } \\
\hline SQ1: Easy to learn & 0.702 & $* * *$ \\
\hline SQ2: Equipped only with useful features and functions & 0.677 & $* * *$ \\
\hline SQ3: Flexible to make changes easily & 0.761 & $* * *$ \\
\hline SQ4: Applied modern technology & 0.808 & $* * *$ \\
\hline SQ5: Well integrated & 0.796 & $* * *$ \\
\hline SQ6: User-friendly & 0.887 & $* * *$ \\
\hline SQ7: Good documentation & 0.823 & $* * *$ \\
\hline SQ8: Short response time for on-line inquiry & 0.802 & $* * *$ \\
\hline Information Quality (Gorla et al., 2010) & \multicolumn{2}{|c|}{ (Likert 7-point scale) } \\
\hline \multicolumn{3}{|l|}{ Our information outputs (including on-screen and printed outputs) are: } \\
\hline IQ1: Accurate & 0.897 & $* * *$ \\
\hline IQ2: Complete & 0.957 & $* * *$ \\
\hline IQ3: Concise & 0.845 & $* * *$ \\
\hline Usefulness (Liao et al., 2007) & \multicolumn{2}{|c|}{ (Likert 7-point scale) } \\
\hline PU1: Using AIS improves my performance in working & 0.915 & $* * *$ \\
\hline PU2: Using AIS improves my productivity in working & 0.935 & $* * *$ \\
\hline PU3: Using AIS enhances my effectiveness in working & 0.895 & $* * *$ \\
\hline PU4: I find AIS to be useful in my job & 0.891 & $* * *$ \\
\hline
\end{tabular}

$* * * \mathrm{P}<0.001$

\begin{tabular}{|c|c|c|c|c|c|c|}
\hline \multirow{2}{*}{ Construct } & \multirow{2}{*}{ CR } & \multirow{2}{*}{ AVE } & \multicolumn{4}{|c|}{ Factor correlation } \\
\hline & & & $\mathrm{ACC}$ & SQ & IQ & PU \\
\hline $\mathrm{ACC}$ & 0.868 & 0.687 & 1 & & & \\
\hline SQ & 0.927 & 0.616 & 0.432 & 1 & & \\
\hline IQ & 0.928 & 0.827 & 0.348 & 0.063 & 1 & \\
\hline PU & 0.950 & 0.812 & 0.419 & 0.657 & 0.622 & 1 \\
\hline
\end{tabular}

Structural equation model results

SEM from path analysis is summarized in Figure 2 and Table 5, in which the goodness of fit, the explained variance of endogenous variables and path coefficients are illustrated. The statistical values Chi-square/df is 3.694, being in a range of acceptable levels of less than 5 (Bentler, 2006). Other indicators also demonstrated a adequate fit (GFI = 0.901, $\mathrm{AGFI}=0.864, \mathrm{CFI}=0.951, \mathrm{TLI}=0.94, \mathrm{RMSEA}=0.079, \mathrm{SRMR}=0.042)($ Gunzler \& Morris, 2015; Pham et al., 2019). 


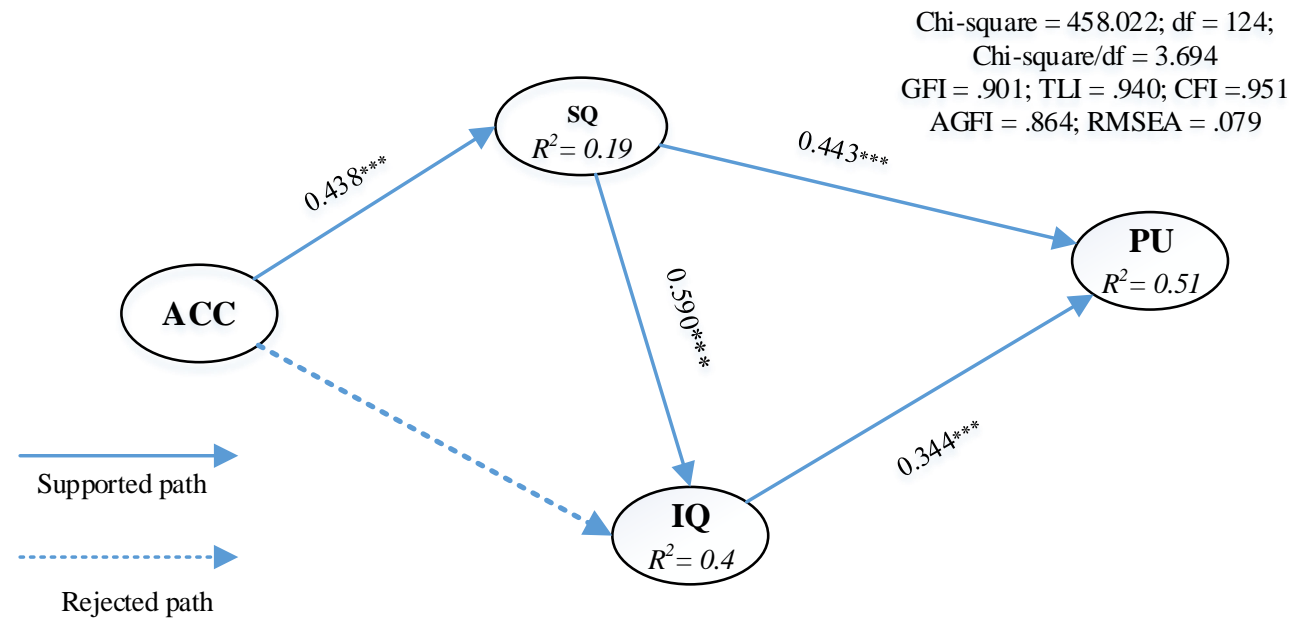

Figure 2. Standardized results of structural equation model

According to standardized estimation results in Table 5, four hypotheses in this study were supported by our empirical analysis of SEM ( $<<=0.001)$, excepting the impact of accountant resource on information quality (H4: $p=$ 0.051). Accountant resource has positive influence on system quality (H5: $\mathrm{p}=0.001)$, system quality has positive effects on information quality $(\mathrm{H} 3: \mathrm{p}=0.001)$, system quality has positive effect on usefulness $(\mathrm{H} 2: \mathrm{p}=0.001)$ and information quality has positive impact on usefulness $(\mathrm{H} 1: \mathrm{p}=0.001)$. Therefore, except for the hypothesis $\mathrm{H} 4$, all other hypotheses were accepted. Besides, the result in Figure 2 illustrated that system quality is predicted by accountant resource, which explained $19 \%$ of the variance in system quality. Information quality was predicted by system quality with $40 \%$ of the variance in information quality. Usefulness was determined by system quality and information quality, which jointly explained $51 \%$ of the total variance explained.

Table 5. Standardized Regression Analysis and hypothesis results

\begin{tabular}{|c|c|c|c|}
\hline & $\beta$ coefficient & t value & Hypothesis \\
\hline \multicolumn{4}{|c|}{ Dependent variable: System Quality } \\
\hline Accountant Resource & 0.438 & $8.282 * * *$ & H5: Supported \\
\hline
\end{tabular}

\section{Dependent variable: Information Quality}

$\begin{array}{llll}\text { Accountant Resource } & 0.094 & 1.951 & \text { H4: Rejected } \\ \text { System Quality } & 0.590 & 11.48 * * * & \text { H3: Supported }\end{array}$

$R^{2}: 40 \%$ of the variance of Information Quality are explained by Accountant Resource and System Quality

\section{Dependent variable: Usefulness}

$\begin{array}{llll}\text { System Quality } & 0.443 & 8.423 * * * & \text { H2: Supported } \\ \text { Information Quality } & 0.344 & 6.839 * * * & \text { H1: Supported }\end{array}$

$R^{2}: 51 \%$ of the variance of Usefulness are explained by System Quality and Information Quality

\section{- Total effects of accountant resource, system quality and information quality on usefulness}

Usefulness is predicted by information quality, system quality calculated by direct and indirect impact through information quality, and indirect effect of accountant resource through two mediators including system quality and information quality. This result depicted that system quality contributed to the highest motivator of usefulness in the model, followed by information quality and accountant resource (Table 6). 
Table 6. Total effects of accountant resource, system quality and information quality on usefulness

\begin{tabular}{|c|c|c|c|}
\hline Antecedent & Direct effect route and magnitude & Indirect effect route and magnitude & Total effect \\
\hline Accountant Resource & l & $\begin{array}{c}\text { Accountant Resource - System Quality - } \\
\text { Usefulness: } 0.438 \text { x } 0.443\end{array}$ & 0.194 \\
\hline Accountant Resource & I & $\begin{array}{c}\text { Accountant Resource - System Quality - } \\
\text { Information Quality - Usefulness: } 0.438 \text { x } \\
0.590 \times 0.344\end{array}$ & 0.089 \\
\hline \multicolumn{2}{|c|}{ Accountant Resource (total) } & & 0.283 \\
\hline System Quality & System Quality - Usefulness: 0.443 & $\begin{array}{c}\text { System Quality - Information Quality - } \\
\text { Usefulness: } 0.590 \times 0.344\end{array}$ & 0.646 \\
\hline Information Quality & $\begin{array}{c}\text { Information Quality - Usefulness: } \\
0.344\end{array}$ & / & 0.344 \\
\hline
\end{tabular}

\section{- Total effects of accountant resource and system quality on information quality}

As shown in Table 7, information quality was predicted by the direct effect of system quality and the indirect effect of accountant resources through mediator system quality.

Table 7. Total effects of accountant resource and system quality on information quality

\begin{tabular}{cccc}
\hline Antecedent & Direct effect route and magnitude & Indirect effect route and magnitude & Total effect \\
\hline Accountant Resource & $/$ & $\begin{array}{c}\text { Accountant Resource - System Quality - } \\
\text { Information Quality: } 0.443 \times 0.590\end{array}$ \\
System Quality & System Quality - Information & 0.258 \\
& Quality: 0.590 & $/$ & 0.590 \\
\hline
\end{tabular}

\section{Discussion}

In this study, we postulate a multidimensional measure to assess the quality of accounting information system including system quality, information quality, and usefulness. This research examines accountant resources using SEM to explore its impact on the quality of accounting information systems. The conceptual model is empirically approved using data collected from a field survey of Vietnamese SMEs located in Hanoi. The CFA results validate and refine the measurement model. In the context of Vietnamese SMEs, item "short time lag between data input and output for batch processing" is removed from the system quality construct. This reveals a simple processing procedure in the accounting information system due to employing the applications for mainly bookkeeping in the accounting information system (Binh, 2017). Three items of information quality are retained while five items removed. Gorla et al. (2010) discussed that "accurate, complete, and concise" reflect information content, meanwhile, eliminated items represent information format. That means information quality in Vietnamese SMEs only meets the requirements of accounting information in Vietnamese Accounting Standards but does not facilitate corporate governance.

While many prior studies used single scales to measure the quality of accounting information systems, our results confirm that the multidimensional scale is a necessity to comprehensively measure accounting information system quality. This research provides empirical evidence for Huynh and Nguyen's study (2013), they suggested use multicriteria to measure accounting information system quality. The acceptance of hypotheses H1, H2, H3 indicates that three proxies of accounting information system quality are not separate, they interact strongly with each other. System quality is a key driver of information quality and usefulness. These results are similar to the study of Gorla et al. (2010) who argued that a system with old hardware and software causes poor outputs, and enhancements in system quality help increase information quality. Moreover, the same as previous results about the effect of system quality on usefulness (Davis, 1989; Sabherwal et al., 2006; Seddon \& Kiew, 1996), this research states the higher system quality, the easier it is for users to feel useful of accounting information system. These empirical results show an increase in information quality causes a rise in usefulness that is consistent with the study of Seddon and Kiew (1996),. 
This empirical study contributes to the main findings to the influence of accountant resources on the quality of accounting information systems. The SEM results showed that constructs in the conceptual model are appropriate. Comparing effect sizes and explained variance, we found that the interaction among accountant resources, system quality, and information quality explained $51 \%$ of the variance of usefulness. Another significant result, the interaction between accountant resource and system quality explained $40 \%$ of the variance of information quality. And accountant resource explained $19 \%$ of the variance of system quality. Explanation level of model, which is shown by R2 values is consistent with previous studies in accounting information system quality, for example, Mokodompit and Wuriasih (2017) $(\mathrm{R} 2=50.3 \%)$, Ismail $(2009)(\mathrm{R} 2=41.1 \%)$ and Fitriati and Susanto (2017) $(\mathrm{R} 2=$ $50 \%)$.

The test results accepted hypothesis H5 while rejecting hypothesis H4. The support of hypothesis H5 shows that accountant resource directly affects system quality. This finding agreed with Hall (2011) that accountants have an important role in coordinating with the information technology specialist to choose the most effective applications and suppliers. They are determinants of system quality. Accountants who are long-term relationships with firm and high competence will help firms minimize risks as well as facilitate accounting information systems. The rejection of hypothesis H4 is consistent with the study of Al-hiyari et al. (2013) but contrary to Chalu's (2012) study. The result can be explained that accountants only communicate accounting information following regulations but not satisfied information demands for corporate governance in Vietnamese SMEs. In other words, accountant resource does not have a key contribution to increasing information quality. This may be lead to accountant resource that has no direct impact on information quality. Although, there is no direct impact on information quality. Through mediator of system quality, accountant resource still has an indirect impact on improving information quality. This means that accountants with positive effects that increase system quality also improve information quality. For example, accountants who implement systems with modern applications, integrate well with other subsystems, set up good system documentation will help information in segment and enterprise reports more accurate, complete, and concise. Through two mediators system quality and information quality, accountant resource is a factor affecting usefulness. Long-term and capable accountants will help improve system quality and then heighten information quality, resulting in users perceiving more useful information. The results in this study confirm that accountant resource is a crucial factor in improving the quality of accounting information systems in Vietnamese SMEs. Accountants are an accounting and business services consultant for managers (Gooderham et al., 2004). The results implied for SMEs need to be continuously train accounting competence as well as increase a relationship with accountant resources. Training is an important solution that helps increase the performance of SMEs (Ipinnaiye, Dineen, \& Lenihan, 2017), and due to the continuous change of accounting and business environment, training is a necessary solution. Meanwhile, the long-term accountant will better understand the system and business characteristics of the firm.

\section{Conclusion}

Research topic on accounting information system quality has gotten a lot of attention in the previous studies of Dehghanzade et al. (2011), Boulianne (2007), and Sajady et al. (2008). However, these studies used one dimension to measure the quality of accounting information systems. This paper investigated accounting information system quality, using a multidimensional scale by a combination of constructs, which differs from previous research. In the context of Vietnamese SMEs, we explored a strong interaction between three components of accounting information system quality. The results confirmed positive influence of accountant resources on system quality. The structural model analysis results showed that accountant resource was a factor affecting the quality of accounting information systems.

This research also had several academic and managerial implications. First, it provided an in-depth explanation of the performance of accounting information systems using non-financial indicators in the context of SMEs. Then, the findings suggested practical implications that SMEs should concentrate on system quality, information quality, and usefulness to enhance accounting information system quality. Second, the influence of accountant resource accounting information system quality suggested improvements in accountant competence and enlargement of the relationship between accountant and firm.

This study has a limitation, we evaluated the impact of accountant resource on accounting information system quality in SMEs without detailing the effect of firm size. Meanwhile, Decree No. 39/2018/ND-CP classifies Vietnamese SMEs into micro, small and medium enterprises (Government, 2018), and firm size has a moderating effect on the business model (Aguilar-Fernández \& Otegi-Olaso, 2018). Thus, further research needs to focus on accounting information system quality under the impact of accountant resources between these types of SMEs. 


\section{References}

Aguilar-Fernández, M. E., \& Otegi-Olaso, J. R. (2018). Firm size and the business model for sustainable innovation. Sustainability, 10(12), 4785. doi: https://doi.org/10.3390/su10124785

AICPA. (1966). Statement of Basic Accounting Theory. New York: AICPA Publication.

Al-hiyari, A., Al-Mashregy, M. H. H., Mat, N. K. N., \& Alekam, J. M. (2013). Factors that affect Accounting information system implementation and accounting Information quality: A Survey in University Utara Malaysia. American Journal of Economics, 3(1), 27-31. doi: 10.5923/j.economics.20130301.06

Allahverdi, M. (2011, 12-14 Oct. 2011). A general model of accounting information systems. Paper presented at the Application of Information and Communication Technologies (AICT), 2011 5th International Conference on, Baku, Azerbaijan.

Bentler, P. M. (2006). EQS 6 Structural Equations Program Manual. Encino, CA: Multivariate Software, Inc.

Bhattacherjee, A. (2001). Understanding information systems continuance: an expectation-confirmation model. MIS quarterly, 25(3), 351-370. doi: 10.2307/3250921

Binh, V. T. T. (2017). Mối quan hệ giũa Quy mô doanh nghiệp với mức độ trang bị công nghệ thông tin và chất luợng hệ thống thông tin kế toán tại các doanh nghiệp Việt Nam [Relationship among firm size and IT sophistication and AIS quality in Vietnamese enterprises]. Paper presented at the Accounting - Auditing and Economics in Vietnam in the context of industrial revolution 4.0, Quy Nhon University.

Binh, V. T. T., \& Luan, D. T. (2017). Nghiên cưu tác động của năng lục đội ngũ kế toán đến chất lương của hệ thống thông tin kế toán tại các doanh nghiệp trong diều kiện phát triển bền vũng tại Việt Nam [Impact of accountant competence to accounting information systems' quality in sustainable development conditions in Vietnam]. Paper presented at the International Academic Conference: Sustainable Production and Consumption, National Economics University.

Boockholdt, J. L. (1995). Accounting information systems: Transaction processing and controls: McGraw-Hill Professional.

Boulianne, E. (2007). Revisiting fit between AIS design and performance with the analyzer strategic-type. International Journal of Accounting Information Systems, 8(1), 1-16. doi: https://doi.org/10.1016/j.accinf.2006.12.001

Chalu, H. (2012). Analysis of Stakeholder Factors Influencing the Effectiveness of Accounting Information Systems in Tanzania's Local Authorities. Business Management Review, 16(1), 1-32.

Chang, S. J., Van Witteloostuijn, A., \& Eden, L. (2010). From the Editors: Common method variance in international business research. Journal of International Business Studies, 41(2), 178-184. doi: doi:10.1057/jibs.2009.88

Chapellier, P., Mohammed, A., \& Teller, R. (2013). Le système d'information comptable des dirigeants de PME syriennes: complexité et contingences [The accounting information system of Syrian SME managers: complexity and contingencies]. Management \& Avenir(7), 48-72.

Chenhall, R. H. (2003). Management control systems design within its organizational context: findings from contingency-based research and directions for the future. Accounting, Organizations and Society, 28(2-3), 127-168. doi: 10.1016/S03613682(01)00027-7

Davis, F. D. (1989). Perceived usefulness, perceived ease of use, and user acceptance of information technology. MIS quarterly, 319-340. doi: 10.2307/249008

Dehghanzade, H., Moradi, M. A., \& Raghibi, M. (2011). A Survey of Human Factors' Impact on the Effectiveness of Accounting Information Systems. International Journal of Business Administration, 2(4), 166-174. doi: Doi:10.5430/ijba.v2n4p166

Delone, W. H. (1988). Determinants of success for computer usage in small business. MIS quarterly, 51-61. doi: DOI: $10.2307 / 248803$

Delone, W. H., \& McLean, E. R. (1992). Information Systems Success: The Quest for the Dependent Variable. Information Systems Research, 3(1), 60-95. doi: https://doi.org/10.1287/isre.3.1.60

Delone, W. H., \& McLean, E. R. (2002). Information systems success revisited. Paper presented at the System Sciences, 2002. HICSS. Proceedings of the 35th Annual Hawaii International Conference on.

Delone, W. H., \& McLean, E. R. (2003). The DeLone and McLean Model of Information Systems Success: A Ten-Year Update. Journal of Management Information Systems, 19(4), 9-30. doi: 10.1080/07421222.2003.11045748

Fitriati, A., \& Susanto, A. (2017). The accounting information system quality improvement through internal control and top management support effectiveness. Journal of Theoretical \& Applied Information Technology, 95(19), 5003-5011.

Ghorbel, J. (2017). A Study of Contingency Factors of Accounting Information System Design in Tunisian SMIs. Journal of the Knowledge Economy, 1-30. doi: https://doi.org/10.1007/s13132-016-0439-8

Gooderham, P. N., Tobiassen, A., Døving, E., \& Nordhaug, O. (2004). Accountants as sources of business advice for small firms. International Small Business Journal, 22(1), 5-22. doi: doi:10.1177/0266242604039478

Gorla, N., Somers, T. M., \& Wong, B. (2010). Organizational impact of system quality, information quality, and service quality. Journal of Strategic Information Systems, 19, 207-228. doi: https://doi.org/10.1016/j.jsis.2010.05.001

Government. (2018). Nghị định 39/2018/NĐ-CP: Quy định chi tiết một số điều của Luật hố trợ doanh nghiệp nhỏ và vìa [Decree no. 39/2018/NĐ-CP: Detailed regulations on some articles of the Law to support small and medium enterprises].

Gunasekaran, A., Rai, B. K., \& Griffin, M. (2011). Resilience and competitiveness of small and medium size enterprises: an empirical research. International journal of production research, 49(18), 5489-5509. doi: 10.1080/00207543.2011.563831

Gunzler, D. D., \& Morris, N. (2015). A tutorial on structural equation modeling for analysis of overlapping symptoms in cooccurring conditions using MPlus. Statistics in medicine, 34(24), 3246-3280. doi: https://doi.org/10.1002/sim.6541 
Hair, J. F., Black, W. C., Babin, B. J., \& Anderson, R. E. (2014). Multivariate Data Analysis: Pearson.

Hall, J. A. (2011). Accounting Information System.: South: Western Publishing Co.

Henry, J. W., \& Stone, R. W. (1994). A structural equation model of end-user satisfaction with a computer-based medical information system. Information Resources Management Journal (IRMJ), 7(3), 21-33. doi: DOI: 10.4018/irmj.1994070102

Huynh, T. H. H., \& Nguyen, M. T. (2013). Đánh giá hiẹ̣u quả của hệ thống thông tin kế toán [Evaluating the effectiveness of accounting information system]. Tạp chí kế toán và kiểm toán, 6, 23-28.

Ipinnaiye, O., Dineen, D., \& Lenihan, H. (2017). Drivers of SME performance: a holistic and multivariate approach. Small Business Economics, 48(4), 883-991. doi: 10.1007/s11187-016-9819-5

Iskanda, D. (2015). Analysis of Factors affecting the success of the application of Accounting Information System. International Journal of Scientific \& technology research, 4(2), 155-162.

Ismail, N. A. (2009). Factors influencing AIS effectiveness among manufacturing SMEs: Evidence from Malaysia. The Electronic Journal on Information Systems in Developing Countries, 38(10), 1-19. doi: https://doi.org/10.1002/j.16814835.2009.tb00273.x

Kraemer, K. L., Danziger, J. N., Dunkle, D. E., \& King, J. L. (1993). The usefulness of computer-based information to public managers. MIS quarterly, 17(2), 129-148. doi: 10.2307/249798

Levy, M., Loebbecke, C., \& Powell, P. (2003). SMEs, co-opetition and knowledge sharing: the role of information systems. European journal of information systems, 12(1), 3-17. doi: https://doi.org/10.1057/palgrave.ejis.3000439

Liao, C., Chen, J.-L., \& Yen, D. C. (2007). Theory of planning behavior (TPB) and customer satisfaction in the continued use of e-service: An integrated model. Computers in Human Behavior, 23(6), 2804-2822. doi: https://doi.org/10.1016/j.chb.2006.05.006

Meiryani. (2014). Influence of User Ability on the Quality of Accounting Information System. International Journal of Economics, Commerce and Management, II(8), 1-11.

Meiryani. (2015). Influence Business Strategy on the Quality of Accounting Information System. International Journal of Scientific \& technology research, 4(2), 80-86.

Merchant, K. A., \& Van der Stede, W. A. (2011). Management control systems: performance measurement, evaluation and incentives. Harlow, UK: Prentice Hall.

Mokodompit, M. P., \& Wuriasih, A. (2017). The Quality of Accounting Information System: a Case of Regional Public Hospital Manokwari. Jurnal Ekonomi Dan Bisnis, 20(2), 275-290. doi: https://doi.org/10.24914/jeb.v20i2.696

MPI. (2017). Sách trắng: Doanh nghiệp nhỏ và vìa Việt Nam [While paper: Small and medium enterprises in Vietnam].

Neely, A., Gregory, M., \& Platts, K. (1995). Performance measurement system design: a literature review and research agenda. International Journal of Operations \& Production Management, 15(4), 80-116.

Nelson, R. R., Todd, P. A., \& Wixom, B. H. (2005). Antecedents of information and system quality: an empirical examination within the context of data warehousing. Journal of Management Information Systems, 21(4), 199-235. doi: https://doi.org/10.1080/07421222.2005.11045823

Ngo, T. T. H., Le, T. K. S., \& Nguyen, T. T. D. (2013). Tác động của hệ thống thông tin kế toán đến mức độ tồn tại gian lận và sai sót trong các doanh nghiệp vừa và nhỏ tại Hà Nội [Impact of accounting information system on the existence fraud and errors in small and medium enterprises]. Tạp chí Khoa học và phát triển, 11(4), 565-573.

Nicolaou, A. L. (2000). A Contigency model of perceived effectiveness in accounting information system: Organizational coordination and control effects International Journal of Accounting Information Systems, 1, 91-105. doi: https://doi.org/10.1016/S1467-0895(00)00006-3

Oakes, H. (2006). The role of accounting discourse in the leaarning and skills council and further education colleges: A multiperspective approach. Manchester Metropolitan University Business School Working paper series, WPS064.

Okab, R., \& Al-Oqool, M. A. (2014). The Role of Accountants in E-accounting Information Systems' Lifecycle at the Jordanian Banking Sector. International Journal of Business and Social Science, 5(4).

Perrini, F., \& Tencati, A. (2006). Sustainability and stakeholder management: the need for new corporate performance evaluation and reporting systems. Business Strategy and the Environment, 15(5), 296-308. doi: https://doi.org/10.1002/bse.538

Petter, S., Delone, W. H., \& McLean, E. R. (2008). Measuring information systems success: models, dimensions, measures, and interrelationships. European journal of information systems, 17, 236-263. doi: https://doi.org/10.1057/ejis.2008.15

Pham, H.-H., Lai, S. L., \& Vuong, Q.-H. (2019). The role of subjective task value in forming satisfaction and loyalty among Vietnamese international students: A structural equation model. Asia-Pacific Edu Res. doi: https://doi.org/10.1007/s40299019-00439-3

Phan, D. D., \& Pham, A. T. (2015). Accounting information system affecting efficiency of Vietnam's small and medium Enterprises in the Asean Economic Community (AEC). Tạp chí phát triển và hội nhập, 20(3), 87-96.

Pitt, L. F., Watson, R. T., \& Kavan, C. B. (1995). Service Quality: A Measure of Information Systems Effectiveness. MIS quarterly, 19(2), 173-187. doi: DOI: 10.2307/249687

Quang Phu. (2018, 12/05/2018). Đại hội Hiệp hội doanh nghiệp nhỏ và vừa TP. Hà Nội [Congress of Small and Medium Enterprises Association in Hanoi]. Retrieved 20/04, 2019, from https://hanoi.gov.vn/tintuc_sukien//hn/ZVOm7e3VDMRM/3/2813173/9/ai-hoi-hiep-hoi-doanh-nghiep-nho-va-vua-tp-hanoi.html;jsessionid=Cdfw1XZCgx9JjK4Z15Bi7Tpq.app2

Romney, M. B., \& Steinbart, P. J. (2015). Accounting information systems: Pearson Boston, MA. 
Sabherwal, R., Jeyaraj, A., \& Chowa, C. (2006). Information system success: individual and organizational determinants. Management Science, 52(12), 1849-1864. doi: https://doi.org/10.1287/mnsc. 1060.0583

Saganuwan, M. U., Ismail, W. K. W., \& Ahmad, U. N. U. (2013). Technostress: mediating accounting information system performance. Information Management and Business Review, 5(6), 270-277.

Sagara, Y. (2015). The Effect of Implementation Accounting Information System and Competence of Human Resources on the Quality of Financial Reporting. Research Journal of Finance and Accounting, 6(10), 111-115.

Sajady, H., Dastgir, M., \& Nejad, H. H. (2008). Evaluation of the effectiveness of accounting information systems. International journal of information science and technology, 6(2), 49-59.

Salavou, H. (2004). The concept of innovativeness: should we need to focus? European Journal of Innovation Management, 7(1), 33-44. doi: https://doi.org/10.1108/14601060410515628

Scupola, A. (2009). SMEs'e-commerce adoption: perspectives from Denmark and Australia. Journal of Enterprise Information Management, 22(1/2), 152-166. doi: https://doi.org/10.1108/17410390910932803

Seddon, P. B. (1997). A respecification and extension of the DeLone and McLean model of IS success. Information Systems Research, 8(3), 240-253. doi: https://doi.org/10.1287/isre.8.3.240

Seddon, P. B., \& Kiew, M. Y. (1996). A Partial Test and Development of Delone and McLean's Model of IS Success. Australian Journal of Information Systems, 4(1), 90-109. doi: http://dx.doi.org/10.3127/ajis.v4i1.379

Shen, J., \& Han, L. (2019). Design process optimization and profit calculation module development simulation analysis of financial accounting information system based on particle swarm optimization (PSO). Information Systems and e-Business Management. doi: 10.1007/s10257-018-00398-0

Susanto, A. (2017). How the Quality of Accounting Information System impact on Accounting Information Quality (Research on Higher Education in Bandung). Journal of Engineering and Applied Sciences, 12(14), 3672-3677.

Taber, T. A. A., Alaryan, L. A., \& Haija, A. A. A. (2014). The effectiveness of accounting information systems in Jordanian Private higher education institutiona. International Journal of Accounting and Financial Reporting, 4(1), 28-42.

Uyar, M. (2019). The management accouting and the business strategy development at SMEs. Problems and Perspectives in Management, 17(1), 1-10. doi: 10.21511/ppm.17(1).2019.01

VCCI. (2017). Báo cáo thường niên doanh nghiệp Việt Nam 2016 [Annual reporting: Vietnameses Enterprises in 2016].

Zhou, L. (2010). The research on issue and countermeasures of accounting information of SMEs. International Journal of Business and Management, 5(3), 223-225.

(C) 2020 by the authors. Licensee ACRN Publishing, Austria, Editor in Chief Prof. Dr. Othmar M. Lehner. This article is an open access article distributed under the terms and conditions of the Creative Commons Attribution (CC BY SA) license

(https://creativecommons.org/licenses/by-sa/4.0/) 